\title{
Water Quality in and around Lake Edward Basin of the Greater Virunga Landscape, D. R. Congo Side
}

\section{Katcho Karume ${ }^{1,2}$, Mashimango Bagalwa ${ }^{1,3 *}$, Espoir Bagula1, Mapendano Yalire ${ }^{2}$, Patrick Habakaramo², James Byamukama ${ }^{4}$, Nachigera Mushagalusa ${ }^{1}$}

\author{
${ }^{1}$ Faculté des Sciences Agronomiques et Environnement, Université Evangélique en Afrique, Bukavu, Congo \\ ${ }^{2}$ Observatoire Volcanologique de Goma, Goma, Congo \\ ${ }^{3}$ Centre de Recherche en Sciences Naturelles de Lwiro, Bukavu, Congo \\ ${ }^{4}$ Greater Virunga Transboundary Collaboration, Kigali, Rwanda \\ Email: *mashibagalwa@gmail.com
}

How to cite this paper: Karume, K., Bagalwa, M., Bagula, E., Yalire, M., Habakaramo, P., Byamukama, J. and Mushagalusa, N. (2019) Water Quality in and around Lake Edward Basin of the Greater Virunga Landscape, D. R. Congo Side. Journal of Environmental Protection, 10, 1174-1193.

https://doi.org/10.4236/jep.2019.109070

Received: May 8, 2019

Accepted: September 13, 2019

Published: September 16, 2019

Copyright $\odot 2019$ by author(s) and Scientific Research Publishing Inc. This work is licensed under the Creative Commons Attribution International License (CC BY 4.0).

http://creativecommons.org/licenses/by/4.0/

\begin{abstract}
A systematic study has been carried out to assess the water quality in and around Lake Edward basin in D.R. Congo Side. Fifty four water samples were collected and analyzed for physicochemical parameters, including: temperature, discharge, $\mathrm{pH}$, electrical conductivity, transparency, dissolved oxygen, COD, BOD, Carbonate, Bicarbonate, alkalinity, total hardness, turbidity, calcium hardness, calcium, magnesium hardness, magnesium, total nitrogen, ammonium, nitrate, total phosphorus, soluble reactive phosphorus, chloride, sulphate and total suspended solids. For bacteriological parameters: fecal bacteria, enterococcus bacteria, vibrio and salmonella shigella bacteria were considered. For macroinvertebrates assemblages all taxa using standards methods for each parameter. A comparison of data from dry (June to August) and wet (September to May) season was done in and around Lake Eduard watershed. The analytical data of various physicochemical parameters indicates that water characteristics in the watershed were in the limit of WHO standards for drinking water and aquatic life. Bacteriological water quality of some ecosystems in the watershed revealed the infestation of water with bacteria which make the water unusable for drinking by the surrounding population near and within Lake Eduard watershed. Longtime period sampling in the watershed is needed to understand the variation and composition of water quality and aquatic macroinvertebrate environment of the watershed.
\end{abstract}

\section{Keywords}

Water Quality, Lake Eduard, Greater Virunga, Landscape, D. R. Congo 


\section{Introduction}

Water is one of the most important and most precious natural resources of the ecosystem. It is essential in the life of all living organisms from the simplest plant and microorganisms to the most complex living system known as human body [1]. All living organisms on the earth need water for their survival and growth. But due to increased human population, industrialization, use of fertilizers in agriculture and man-made activity, water is highly polluted with different harmful contaminants. Therefore it is necessary that water quality be checked at regular time intervals to avoid human diseases and biodiversity losses [2] [3] [4] [5].

Natural water contains different types of impurities as well as introduced impurities in different ways such as weathering of rocks and runoff of surface soils, atmospheric deposition of aerosol particles and from several human activities [6] [7]. High levels of pollutants mainly organic matter in river water cause an increase in biological oxygen demand [8], chemical oxygen demand, total dissolved solids, total suspended solids and fecal coli form. They make water unsuitable for drinking, irrigation or any other use [9].

The increased use of heavy metal pollution in agriculture and industry could result in a continued rise of the concentration in freshwater and production of chronic poisoning in aquatic animals and human [10]. Furthermore, fecal pollution of water causes water born disease, which has led to the death of millions of people and can affect also other biodiversities in water bodies [11]. Therefore, water quality concerns are often the most important component for measuring access to improved water sources. To ensure the safety of drinking water, acceptable quality in terms of its physical, chemical and bacteriological parameters should be checked [7]-[12].

Lake Edward is a large watershed with varied ecosystems, rich in biodiversities such as a wide variety of fish species and other aquatic resources [13]. However, the excessive use of various agrochemicals in the nearby lands of the rivers, uncontrolled urbanization, lack of well-planned development on the river banks and population growth are increasingly polluted the watershed water ecosystems. The surrounding lands are used for agricultural activities and water of these ecosystems is generally used for irrigation purposes and drinking water for the population as well as animals. People nearby the rivers and Lake use these water ecosystems for washing their clothes, bathing, washing their cattle, etc. These anthropogenic activities may degrade the quality of water in Lake Edward basin. According to Kilham [14] and Lehman [15], despite their ecological, evolutional and geological roles, the real ecology and chemistry of the rivers in the broad south-eastern plain, and others that flow across the western Mitumba escarpment into Lake Edward are essentially unknown and unmeasured.

However, no water quality or water quantity data exists for tributaries rivers and the lake itself, except the work of Talling and Talling [16] and Bagalwa et al. [17], who studied the water quality in some rivers feeding Lake Edward. The re- 
sults of their studies showed that water quality was suitable for aquatic life and some selected microorganisms consisting of total coliform, fecal coliform (Escherichia coli) and Vibrio cholera were present. Nevertheless, they didn't consider in their studies heavy metals and anions concentrations, which also play a vital role in assessing water quality along with physicochemical and bacteriological (microorganisms) parameters.

A basic understanding of Lake Eduard watershed is necessary for park managers to preserve the high quality of water resources and the biodiversity using the water [13]. This includes not only Lake Eduard, but the inflows to the lake as well. It is hypothesized that the quality of water in the catchment of the lake Eduard is deteriorated by anthropogenic activity taking place actually. Obtaining knowledge of the entire watershed could lead to a better understanding of the spawning habitat of fish and other unique biodiversities in the Lake but also in the entire Virunga National Park catchment.

The present study was conducted to assess the water quality of the ecosystems in and around Lake Edward watershed with respect to physicochemical parameters and major heavy metals concentrations, bacteriological parameters as well as macroinvertebrates assemblages.

\section{Materials and Methods}

\subsection{Sampling Site}

The study area covers Lake Edward and its catchment area in DR Congo side. The catchment of Lake Edward covers $15,840 \mathrm{~km}^{2}$. The lake is fed primarily by rivers draining the surrounding mountains. In addition, the Kazinga Channel, a $30 \mathrm{~km}$-long, $1 \mathrm{~km}$-wide, drowned river valley that flows from Lake George (914 $\mathrm{m}$ a.s.l.) to the east, is a major inflow. Lake George is mainly fed by streams draining the Rwenzori Mountains [18]. Currently, Lake Edward overflows into the Semliki River, which runs northwards into Lake Albert and hence to the White Nile like Figure 1 shows.

The annual rainfall varies from 650 - $900 \mathrm{~mm}$ [19]. The monthly mean maxima of temperature vary from $26.3^{\circ} \mathrm{C}$ in January to $30^{\circ} \mathrm{C}$ in September, while the minima vary from $15.5^{\circ} \mathrm{C}$ to $17.8^{\circ} \mathrm{C}$. The absolute maximum temperature is of $32^{\circ} \mathrm{C}$ generally in February, and the absolute minimum temperature is of $14^{\circ} \mathrm{C}$ generally recorded in January, February, June and July [13] [20].

\subsection{Physicochemical Analysis}

Two methods were used to determine the quantity of water at the sampling sources. Discharge from rivers was measured by determining the velocity of a floating object and the total cross-sectional area of the river following the Floating Method procedure [21] [22]. For source and borehole bucket and stopwatch method was used. Very easy method to estimate discharge by simply measuring the time it takes to fill a container of a known volume. This method only works for systems with fairly low flow volume. A bucket of 10 liters was placed 


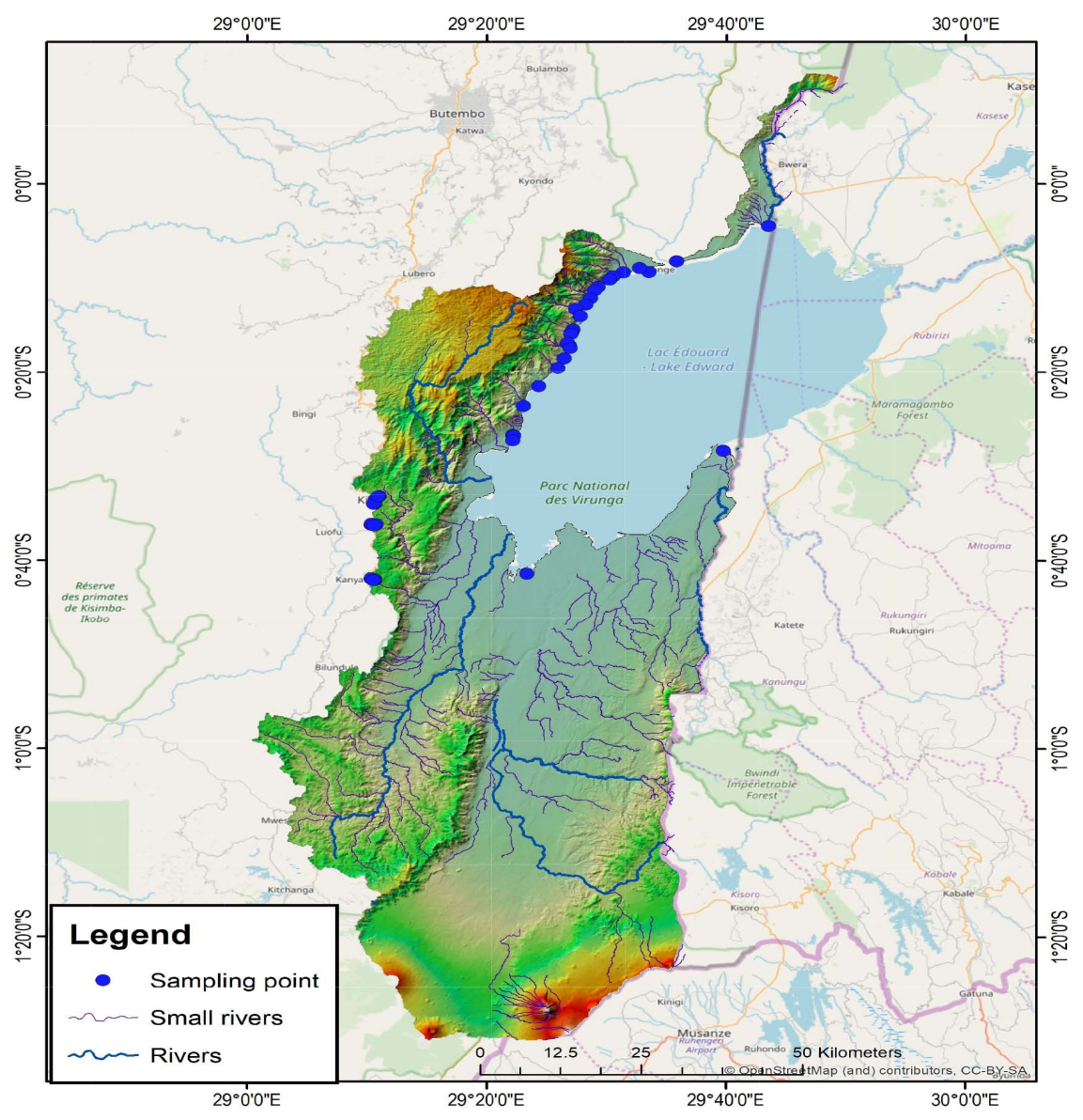

Figure 1. Study area and sampling sites, Lake Edward Basin Congo side.

underneath in order to capture all the discharge and a stopwatch was used to estimate the time necessary to fill the bucket [23].

Surface water temperature, $\mathrm{pH}$, Conductivity, Transparency, Dissolved Oxygen (DO), five-day Biological Oxygen Demand $\left(\mathrm{BOD}_{5}\right)$, Chemical Oxygen Demand (COD), Total Hardness, Calcium, Magnesium, Chloride, Sulphate, Fluoride, Hydro-carbonate, Free $\mathrm{CO}_{2}$, Total phosphorus, soluble reactive phosphorus, Total nitrogen, Ammonium, Nitrate and Total Suspended Solide (TSS) were measured in different sites and analyzed following the procedures described in Golterman et al. [24], APHA [25], Wetzel and Liken [26].

Samples were collected during different times of the day. At each sampling point, two water samples were collected in prewashed glass bottles. Water was collected at a depth of $30 \mathrm{~cm}$, near midstream in plastic bottles at the same time, for other chemical analyses (heavy metals). The plastic bottles were rinsed before overnight with $1 \mathrm{M} \mathrm{HCl}$ and then with distilled water. At the site, bottles were also rinsed thrice with sample water before final collection. The samples were placed in a cooler box with ice for transportation at Goma Volcano Observatory laboratory. Analyses were not done immediately upon arrival at the laboratories; samples were stored in a refrigerator at $4^{\circ} \mathrm{C}$ with preservation as appropriate. In situ, temperature was measured using an YSI PROFESSIONAL PLUS. The 
meter sensor was dipped into the water and the temperature reading was recorded after the meter had stabilized. The $\mathrm{pH}$ was determined using the same YSI PROFESSIONAL PLUS, which was first standardized with two buffers (4 and 10). The conductivity was also measured in situ with the same equipment. Transparency of the water was determined with the aid of Secchi disc. The calibrated disc was lowered into the water and the depth at which it disappeared observed and recorded. The level of DO in the water was determined after fixation in the field, following the iodometric Winkler's method [24] [27]. $\mathrm{BOD}_{5}$ was measured as the decrease in $\mathrm{DO}$ after incubation in the dark at $20^{\circ} \mathrm{C}$ for five days. The $\mathrm{BOD}_{5}$ in $\mathrm{mg} / \mathrm{L}$ of $\mathrm{DO}$ was calculated by subtracting the $\mathrm{mg} / \mathrm{L}$ of $\mathrm{DO}$ in incubated sample bottles from the DO in initial bottles [28]. Hydro-carbonate $\left(\mathrm{HCO}_{3}^{-}\right.$) was estimated titrimetrically using $0.1 \mathrm{~N} \mathrm{HCl}$ with phenolphtalein and bromocresol as indicators (5\%). Total hardness determined by complexometric method using EDTA after added a tampon and Eriochrome $\mathrm{T}$ indicator. Calcium hardness also was determined by complexometric method using mirixid indicators. Magnesium was determined by subtracting the Total hardness and calcium hardness. The Chloride was determined by titration with silver nitrate and potassium chromate indicator [24]. The sulfate was determined using gravimetrical method. TSS $\left(\mathrm{mg} \cdot \mathrm{l}^{-1}\right)$ was estimated by filtration of water samples through analytical filter paper (Whatman 589, $185 \mu \mathrm{m}$ pore size), which was dried at $105^{\circ} \mathrm{C}$ and pre-weighed [25]. The nutrients (TN, $\mathrm{NO}_{3}^{-}, \mathrm{NH}_{4}^{+}, \mathrm{TP}$ and $\mathrm{PO}_{4}^{3-}$ ) were determined using a spectrophotometer (UNICO 1200 at $630 \mathrm{~nm}$ for nitrogen and $850 \mathrm{~nm}$ for phosphorus). All measurements were made in duplicate. Data were compared with UNECE [29]; FEPA, [30] and WHO [31] standards.

\subsection{Heavy Metal Analysis}

Collected sub-samples were sent to INES regional laboratory for heavy metal testing. Lead, Cadmium, Zinc, Nikel, Chronium, Selenium, Iron, and Mercurywater content were determined. For analysis of $\mathrm{Cd}, \mathrm{Pb}, \mathrm{Ni}, \mathrm{Zn}$ and $\mathrm{Cu}$ direct determination by flame atomic absorption spectrometry as described in ISO 8288 [32] was used. The test sample was acidified by adding nitric acid in order to obtain a $\mathrm{pH}$ of 1 to 2 . An acidified sample portion of $100 \mathrm{ml}$ was used for analysis. Calibration solutions were also prepared using standard solutions of 1000 ppm (Sigma Aldrich Inc.) for each element. Absorptions of calibration solutions were measured and standard curves were plotted. Test solutions were also tested and absorptions obtained were projected on the standard curves to get the corresponding concentrations. Results were reported in $\mathrm{mg} / \mathrm{l}$.

Mercury was determined using AAS method after tin(II) chloride reduction without enrichment as described in ISO 12,846 [33] and Iron as described in ISO 6332 [34]. Calibration curve were prepared by measuring the absorbance standard solution of respectively mercury and iron at different concentrations. Results were reported in $\mathrm{mg} / \mathrm{l}$. 


\subsection{Bacteriological Analysis}

Samples were collected in clean, sterile polypropylene $200 \mathrm{~mL}$ bottles. Before the bottles were washed with deionized water and sterilized in the oven at $60^{\circ} \mathrm{C}$ overnight. At the field, bottles were washed thrice before collecting sample. All samples were kept in refrigerated cool box and transported to the laboratory. All analyses were completed at the Laboratory of Bacteriology at Goma Volcano Observatory. Analyses for total coliform, fecal coliform and fecal streptococci were made in accordance with standard methods [25]. Nutrient agars (NA), Salmonella-shigella agar, Thiosulphate citrate bile salt sucrose agar were used to determine heterotrophic bacterial, Salmonella and Shigella, Vibrio cholera respectively [35].

Due to insecurity reasons in the region, we were not able for streams and rivers to follow an upstream to downstream gradient. Sampling was done both for the wet season (September to May) and the dry season (June to August).

\subsection{Macroinvertebrate Sampling and Analysis}

The benthic macro-invertebrates were collected using a standard form hand-net of $30 \mathrm{~cm}$ wide, $20 \mathrm{~cm}$ high and $50 \mathrm{~cm}$ long with mesh size of $500 \mu \mathrm{m}$. They were collected along the river stretch in a stream direction with an effective sampling effort of 10 minutes per person [36]. The presence of stones in the river bed and water plants were taken in the hand-net and washed in a bucket to collect macro-invertebrate attached. The collected organisms were stored and preserved in formalin $4 \%$ on the field. Identification was made at the malacology laboratory of up to the species level when possible using the keys of determination of Needhan and Needham [37] and Micha and Noiset [38]. If the species were not fund in the key, the identification was restricted to the family or genus level.

\section{Results and Discussion}

The highest temperature in the watershed was recorded at Vitshumbi fountain $\left(28.6^{\circ} \mathrm{C}\right)$ and the lowest was recorded at Muwe River $\left(19.2^{\circ} \mathrm{C}\right)$. This temperature is higher than the temperature recorded in Mikeno sector $\left(16^{\circ} \mathrm{C}\right.$ to $\left.20^{\circ} \mathrm{C}\right)$ by Karume et al., [39]. Temperature is an important water factor because the rate of chemical reactions increases at higher temperatures, which in turn affects biological activities and growth of aquatic organisms [40]. The temperature was conform to the WHO recommended range of $20^{\circ} \mathrm{C}-32^{\circ} \mathrm{C}$ and will not constitute any problem to the residents [12]. $\mathrm{pH}$ varied from 9.39 in Semuliki river to 3.23 in Biondi ground water. This range is out of range of the WHO standards for drinking water [12]. Ground water sustainability is a major challenge because the ground water is a widely distributed resource that is affected by local users and contamination [41]. Electrical conductibility is high in Rutshuru River (1882 $\mu \mathrm{S} / \mathrm{cm})$ and low EC was recorded in river sans nom $(38 \mu \mathrm{S} / \mathrm{cm})$. These highest values in Rutshuru River show the influence of human activities on the physical quality of water in the living place where river crosses. The variation of EC is 
observed in all the sampling sites as also observed in other studies in the same watershed [42] and inrivers in Cote d'Ivoire [43] [44]. Two rivers were dry during this dry season in the watershed and the discharge varied from river to river and springs during the period of study. Turbidity also varied from sampling points, but it is low in spring and fountain except in Vitshumbi fountain where turbidity is high (180 NTU). The highest value was recorded at Lubiriya River sampling site (743 NTU). Chloride varied from $156 \mathrm{mg} / \mathrm{L}$ (Katiri fountain) to 24 $\mathrm{mg} / \mathrm{L}$ (Ancien Muramba). Concentrations of chloride in all the sampling sites were in the range of the WHO standards for drinking water [12]. Dissolved Oxygen (DO) and Chemical Oxygen Demand (COD) varied in sampling sites during the dry season. Water from sampling sites was very well oxygenated. Generally the DO concentration is higher than $5 \mathrm{mg} / \mathrm{L}$. COD and $\mathrm{BOD}_{5}$ show generally an inverse curve. When $\mathrm{BOD}_{5}$ is high $\mathrm{COD}$ is low. Alkalinity varied from $508 \mathrm{mg} / \mathrm{L}$ (Rutshuru River) to $4 \mathrm{mg} / \mathrm{L}$ ( $4 \mathrm{mg} / \mathrm{L}$ ). The highest value of Total hardness was recorded in the river Lubiriya $(12.32 \mathrm{mg} / \mathrm{L})$ and the lowest in the river Kisaka and Ikanga 1 River $(1.15 \mathrm{mg} / \mathrm{L})$ but for Calcium Hardness the highest value was recorded in Ikanga 2 River $(5.44 \mathrm{mg} / \mathrm{L}$ ) and at Ancien Muramba $(0.29 \mathrm{mg} / \mathrm{L})$. Magnesium Hardness varied all from site to site with the highest value recorded in Lubiriya River $(6.36 \mathrm{mg} / \mathrm{L})$ and the lowest value in Kyavinyonge $800 \mathrm{~m}$ large $(0 \mathrm{mg} / \mathrm{L})$. The highest concentration of Sulfate was recorded in Ancien Muramba River $(364.8 \mathrm{mg} / \mathrm{L})$ and the lowest concentration in Muwe River (3.84 mg/L). Except Ancien Muramba, all other sampling sites are in the range of standards for drinking water [12] as indicated in Table 1. Total Phosphorus concentration is high in Lubiriya River $(2.16 \mu$ mole/L) while Soluble Reactive Phosphorus concentration is high in Kisaka spring $(1.63 \mu \mathrm{mole} / \mathrm{L})$. Total Nitrogen and Nitrate concentration are high in Lubiriya River $(29.89 \mu \mathrm{mole} / \mathrm{L}$ and $26.68 \mu \mathrm{mole} / \mathrm{L}$ ). Total Suspend Solid varied also from sampling sites. The highest concentration of TSS is recorded in Lubiriya River $(0.29 \mathrm{~g} / \mathrm{L})$.

There were significant occurrences in some physicochemical parameters which call for caution on discharge untreated waste into Lake Eduard. The sampling sites near populated villageson the lake shore were found to have high concentrations of pollutants. It is a common practice for people living along the lake watershed to discharge their domestic waste as well as human excreta into rivers, which transport them in the Lake. Wild and Domestic animals using the same drinking water can also contaminate the water through direct defecation and urination [45] [46] and caused increase of physicochemical parameters. The high loads of pollutants were more prominent in rainy season as compared to dry seasons. Comparative results of physics parameters during the dry and wet seasons in 2015-2016 for rivers, surface lake water, springs, ground water and fountains in Lake Eduard watershed are present in Table 2.

There were in general no significant differences in the values between the wet season and the dry season $(\mathrm{P}<0.05)$ in Lake Eduard watershed. But some physical parameters values increased and others decreased. Some rivers discharges could not be taken over the two period and others disappear in dry season. 


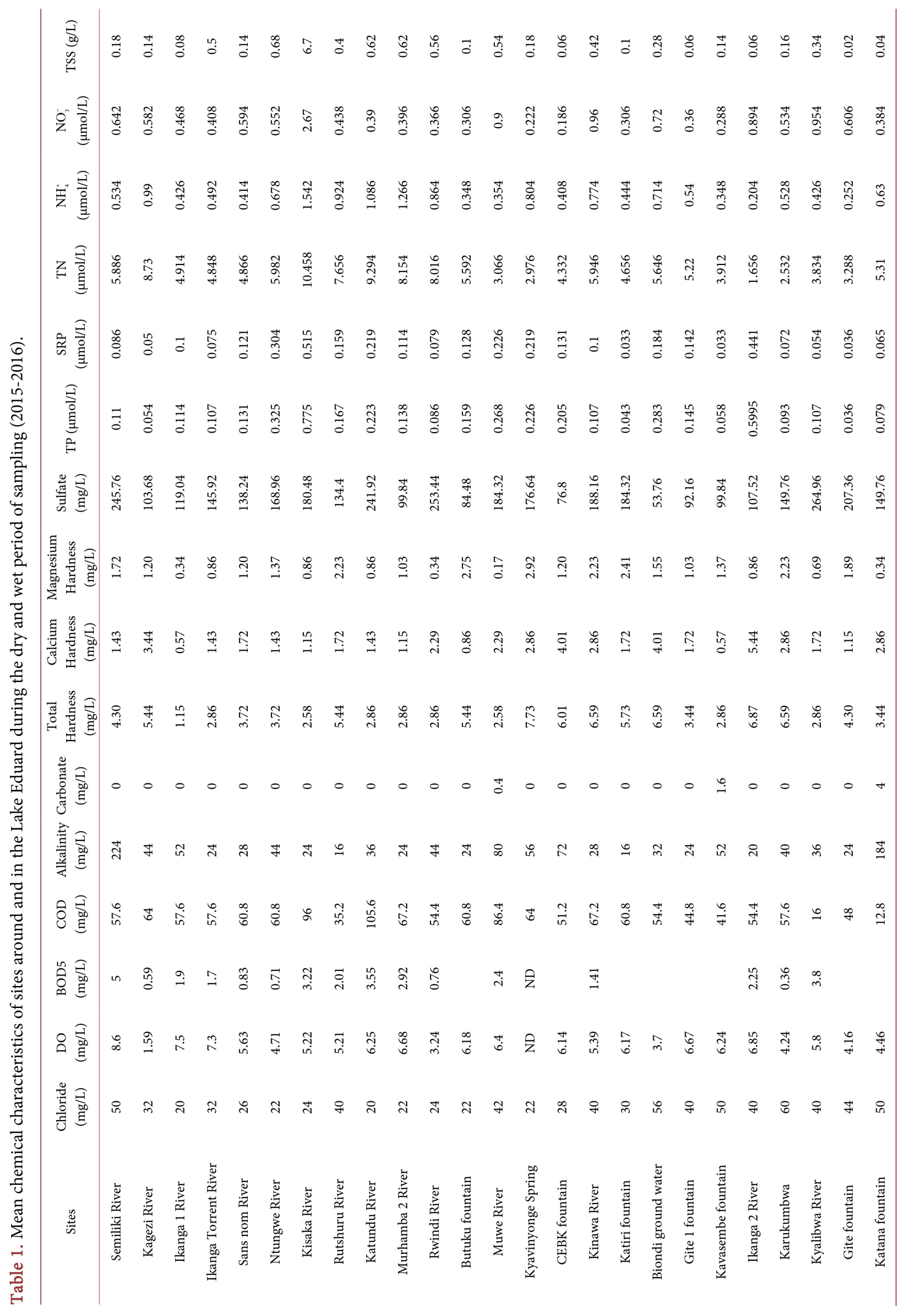




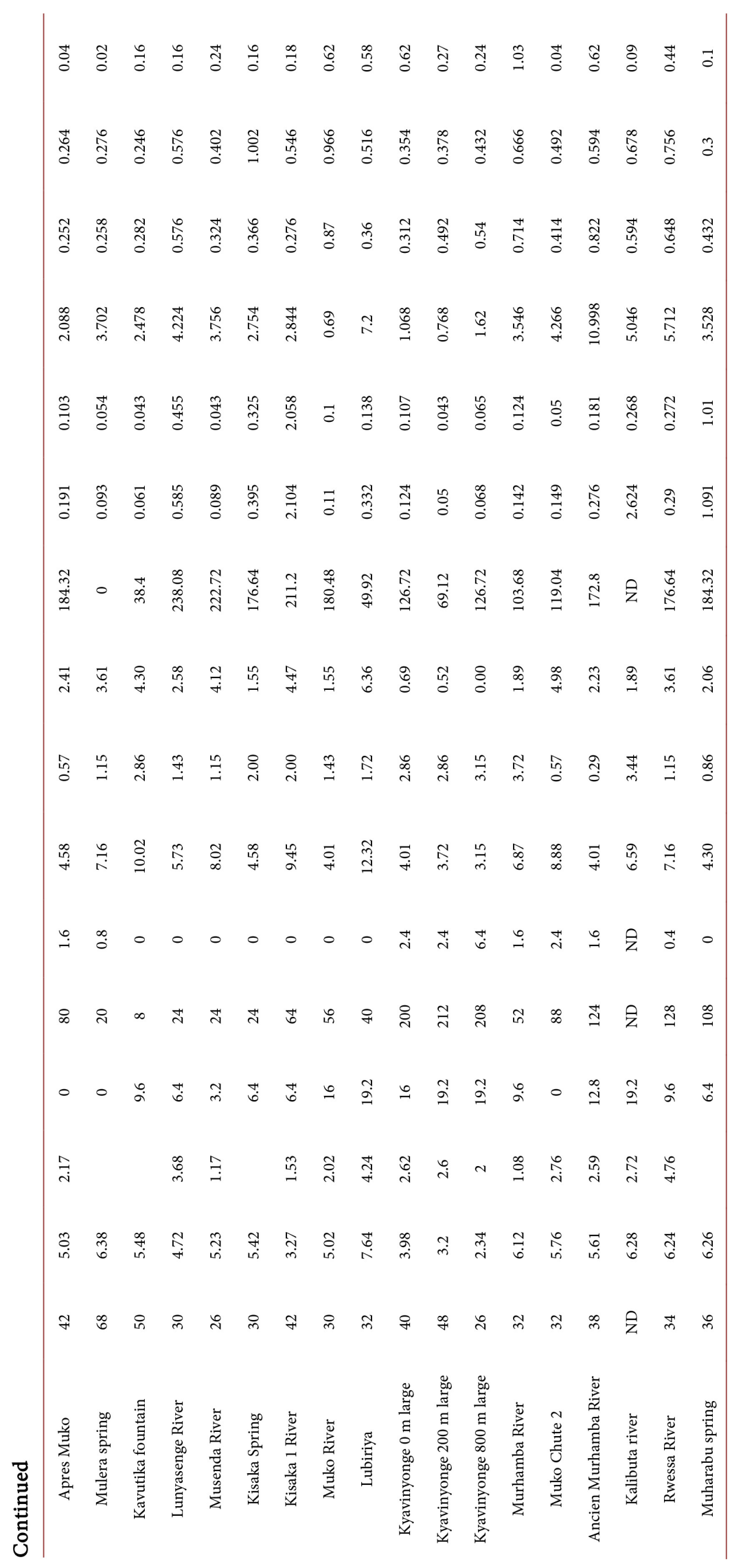


Table 2. Physics parameters of rivers, ground water, lake water, springs and fountains in Lake Eduard watershed in dry and wet seasons (2015-2016).

\begin{tabular}{|c|c|c|c|c|c|c|c|c|c|c|c|c|}
\hline \multirow[b]{2}{*}{ Sites } & \multicolumn{2}{|c|}{ Temperature $\left({ }^{\circ} \mathrm{C}\right)$} & \multicolumn{2}{|c|}{$\mathrm{pH}$} & \multicolumn{2}{|c|}{$\mathrm{EC}(\mu \mathrm{S} / \mathrm{cm})$} & \multicolumn{2}{|c|}{ TDS (mg/L) } & \multicolumn{2}{|c|}{ Tutbidity (NTU) } & \multicolumn{2}{|c|}{ Discharge $\left(\mathrm{m}^{3} / \mathrm{s}\right)$} \\
\hline & Dry & Wet & Dry & Wet & Dry & Wet & Dry & Wet & Dry & Wet & Dry & Wet \\
\hline Semuliki river & 25.7 & 28.2 & 9.39 & 7.98 & 874 & 79.1 & 435 & 158 & 83 & 80 & 40 & 60 \\
\hline Kagezi river & 25.4 & 25.4 & 7.64 & 6.92 & 92 & 77.3 & 46 & 154 & 249 & 45 & ND & 7.53 \\
\hline Ikanga 1 River & 22.8 & 22.4 & 8.84 & 7.84 & 203 & 54.6 & 102 & 109 & 94 & 28 & $\mathrm{~T}$ & $\mathrm{~T}$ \\
\hline Ikanga Torrent River & 23.1 & 22.6 & 8.25 & 7.69 & 96 & 125 & 48 & 250 & 114 & Clear & 0.004 & $\mathrm{~T}$ \\
\hline Sans nom River & 22.3 & 23.6 & 8.32 & 7.01 & 38 & 44.1 & 19 & 88 & 75 & Clear & 0.02 & 0.9 \\
\hline Ntungwe River & 23.5 & 22.7 & 8.22 & 7.98 & 187 & 92.2 & 94 & 184 & 361 & 12 & 0.005 & 0.8 \\
\hline Kisaka River & 22.1 & 23 & 7.14 & 7.58 & 61 & 25 & 30 & 50 & 107 & 0 & 0.09 & 3.41 \\
\hline Rutshuru River & 23.7 & 21.4 & 8.35 & 6.9 & 1882 & 1627 & 944 & 3250 & 86 & 100 & 40 & 17.85 \\
\hline Katundu River & 22.4 & 23.1 & 5.59 & 7.04 & 108 & 67.1 & 54 & 134 & 77 & 7 & 0.02 & 4.85 \\
\hline Murhamba 2 River & ND & 21.5 & ND & 7.87 & ND & 35.2 & ND & 70 & ND & 26 & ND & 0.9 \\
\hline Rwindi River & 21.2 & 20.5 & 7.98 & 6.55 & 226 & 679.4 & 113 & 1358 & 233 & 16 & 1.5 & 18 \\
\hline Butuku fountain* & 21 & 21.4 & 7.4 & 6.67 & 96 & 77.8 & 48 & 155 & 75 & ND & ND & 0.75 \\
\hline Muwe River & 19.2 & 22.3 & 7.52 & 7.66 & 407 & 262 & 204 & 524 & 416 & Clear & 0.0012 & 0.021 \\
\hline Kyavinyonge Spring & 26.9 & $\mathrm{ND}$ & 8.86 & 7.8 & 207 & ND & 104 & ND & 75 & ND & ND & ND \\
\hline Kasando (CEBK) fountain* & 21.2 & 20.9 & 7.14 & 6.35 & 352 & 313.3 & 178 & 626 & 75 & ND & 0.05 & 0.06 \\
\hline Kinawa Spring & 23.6 & 23.4 & 7.43 & 6.91 & 97 & 288 & 48 & 576 & 75 & Clear & ND & 0.015 \\
\hline Katiri (Tsero) fountain ${ }^{*}$ & 23 & 23.4 & 6.27 & 6.92 & 329 & 71.9 & 165 & 143 & 121 & ND & ND & 0.37 \\
\hline Biondi (Libulu) ground water & 20.8 & 21.1 & 3.23 & 8.21 & 590 & 522 & 295 & 1044 & 84 & 34 & ND & ND \\
\hline Mutikili (Gite 1) fountain* & 26.4 & 25.2 & 8.04 & 7.24 & 168 & 118.7 & 84 & 237 & 85 & ND & ND & 0.9 \\
\hline Kavasembe river ${ }^{*}$ & 23.7 & 21.8 & 3.84 & 7.35 & 325 & 76.3 & 161 & 152 & 167 & ND & 0.00004 & 0.99 \\
\hline Ikanga 2 River & 23.1 & 21.4 & 8.98 & 8.3 & 92 & 27 & 46 & 54 & 79 & 19 & $\mathrm{~T}$ & $\mathrm{~T}$ \\
\hline Kasado (Karukumbwa) river & 20.6 & 21.8 & 3.98 & 6.58 & 347 & 297.2 & 173 & 594 & 112 & Clear & 0.2 & 0.015 \\
\hline Kyalimbwa River & 22.3 & 21.6 & 7.76 & 6.7 & 334 & 192 & 167 & 384 & 197 & Clear & 1.6 & 5 \\
\hline Singamwambe (Gite) fountain* & 22.3 & 23.7 & 7.66 & 7.5 & 138 & 111.8 & 69 & 223 & 75 & ND & ND & 0.6 \\
\hline Kinawa (Katana) fountain* & 23.6 & 28.4 & 7.43 & 7.88 & 97 & 794 & 48 & 1588 & 75 & ND & ND & 0.43 \\
\hline Apres Muko river & 23.4 & 24.2 & 8.31 & 7.99 & 87 & 86 & 43 & 172 & 79 & Clear & 0.0003 & 0.07 \\
\hline Mulera spring* & 26.2 & 23 & 5.87 & 7.45 & 60 & 55.2 & 30 & 110 & 75 & ND & ND & 0.37 \\
\hline Kavutika fountain ${ }^{\star}$ & 22.9 & 21.4 & 5.98 & 7.1 & 352 & 282 & 176 & 564 & 75 & ND & 0.25 & 0.3 \\
\hline Lunyasenge River & 22.7 & 24.1 & 7.2 & 7.71 & 141 & 81.3 & 71 & 162 & 83 & 14 & 0.1 & ND \\
\hline Musenda River & 21.4 & 21.8 & 8.59 & 7.6 & 97 & 57.7 & 48 & 115 & 75 & 49 & 0.12 & 5.86 \\
\hline Kisaka Spring* & 25.6 & 23.1 & 7.46 & 6.94 & 109 & 98.2 & 54 & 196 & 75 & ND & 0.18 & 0.37 \\
\hline Kisaka 1 River & $\mathrm{D}$ & 22.5 & ND & 7.25 & ND & 194.7 & ND & 389 & ND & 11 & ND & ND \\
\hline Muko River & 23.3 & 22.5 & 8.53 & 8.9 & 67 & 49 & 34 & 98 & 75 & 62 & 0.015 & 2.3 \\
\hline Lubiriya river & 22.6 & 23.1 & 7.74 & 8.6 & 183 & 111.7 & 92 & 223 & 743 & 23 & 2.5 & 18.75 \\
\hline
\end{tabular}




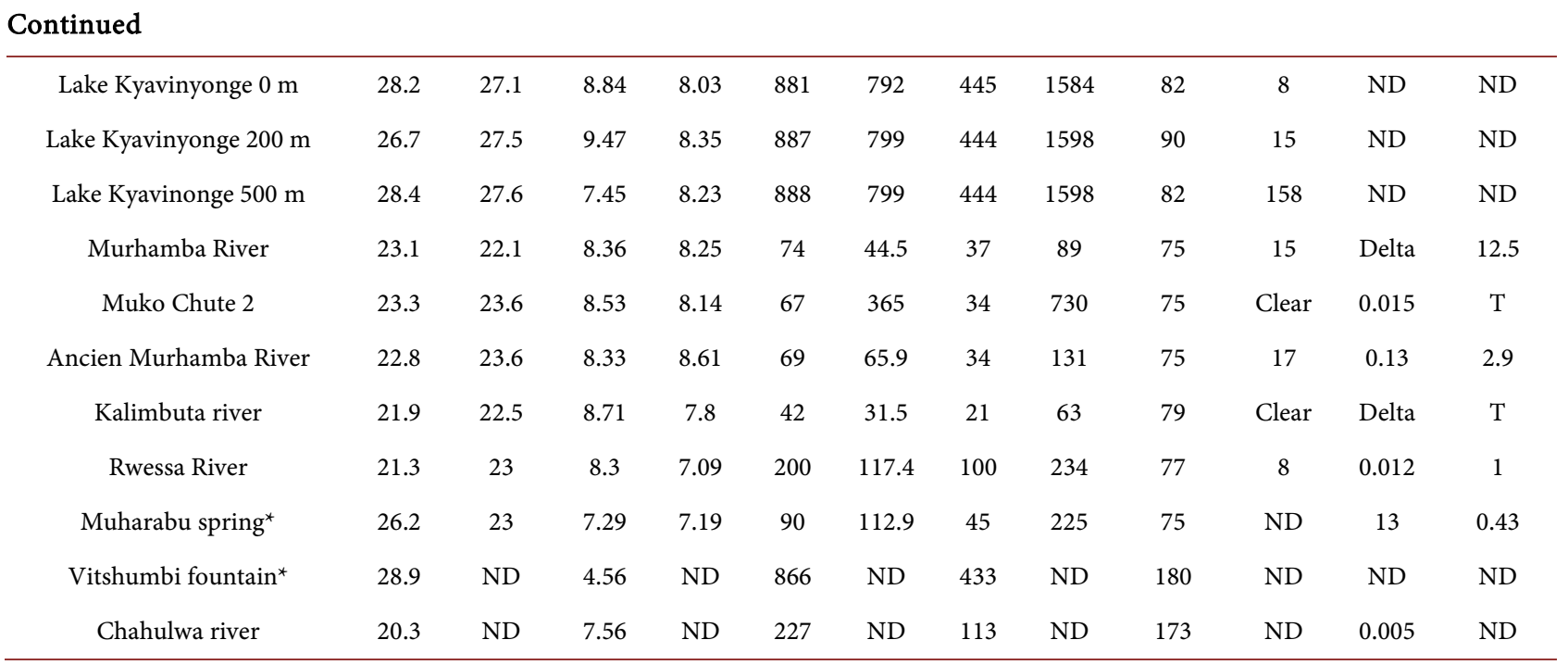

Legend: ${ }^{\star}$ Discharge in $\mathrm{L} / \mathrm{sec}, \mathrm{T}$ : Torrent, ND: No data, D: Disappeared.

Heavy metal characteristics of water in and around Lake Eduard ecosystem are presented in Table 3 below.

Results reveal that the concentration of heavy metal is low in water in and around Lake Eduard to standards for natural potable water WHO [12]. That situation is probably due to the nature of the bedrock in the watershed and localization of rivers in a forest where human activities are not common. But with the population increase in the region in search for food this situation may change and water became polluted. Then a regular checking of water quality in the region is recommended to keep the Lake Eduard pristine to diver's heavy metal contamination.

Bacteriological analysis of water in different sampling sites is present in Table 4 below.

During the sampling period in Lake Eduard watershed, 6 types of bacteria contaminated water in and around Lake Eduard watershed. The results show that, six sampling sites were contaminated with Escherichia coli, 8 with Klesbiella, 3 with Citrobacter, 13 with Enterobacter, 1 with Salmonella and 2 with Vibrion cholera. Among the sampling points, 27 were found with one or two contaminating bacteria and 14 were found exempts with bacterial contamination. In Dry season two sampling points were contaminated with the Vibrion cholera contrary to the sampling in wet season. Vibrio cholera and Salmonella were reported in samples in Lake Eduard and its tributaries before in the study conducted by Bagalwa et al. [42], their presence in the samples confirms that these bacteria are present in Lake Eduard watershed and these occur in dry season. Bagalwa et al. [42] carried out their study in the same watershed (Lake Eduard) collecting water from sites different from the present study, and at different time of the year, but the presence of these bacteria was also indicated. This confirms that these bacteria are present in the watershed. It was reported diarrhea diseases in some villages as Lunyansenge caused by consumption of contaminated water and 
Table 3. Heavy metal characteristics (means in $\mathrm{mg} / \mathrm{L}$ ) of rivers, ground water, lake water, springs and fountains in Lake Eduard watershed (2015-2016).

\begin{tabular}{|c|c|c|c|c|c|c|c|c|c|}
\hline & $\mathrm{Hg}(0.001)^{*}$ & $\mathrm{Cu}(1.00)$ & $\mathrm{Cd}(0.003)$ & $\mathrm{Fe}(0.3)$ & $\operatorname{Zn}(5)$ & $\mathrm{Pb}(0.01)$ & $\mathrm{Ni}(0.02)$ & $\mathrm{Cr}(0.05)$ & $\mathrm{Se}(0.01)$ \\
\hline Ikanga 1 River & 0.0012 & 0.00012 & 0.00098 & 0.0007 & N.D. & N.D. & 0.00058 & 0.0058 & 0.0014 \\
\hline Ikanga torrent River & 0.0003 & 0.00012 & N.D. & 0.0003 & 0.0004 & N.D. & 0.00055 & 0.0223 & 0.0017 \\
\hline San nom River & 0.00195 & 0.00012 & 0.00064 & 0.0007 & 0.0074 & N.D. & 0.00055 & 0.0053 & 0.0018 \\
\hline Kisaka River & 0.0012 & 0.00004 & N.D. & 0.0008 & N.D. & 0.00092 & 0.00042 & N.D. & 0.0029 \\
\hline Katundu River & N.D. & 0.00004 & N.D. & 0.0007 & N.D. & 0.00002 & 0.00053 & 0.0075 & 0.0025 \\
\hline Murhamba 2 River & 0.00045 & N.D. & 0.00081 & N.D. & 0.0039 & 0.00029 & 0.00039 & 0.0057 & 0.0014 \\
\hline Rwindi River & N.D. & 0.00004 & N.D. & 0.0008 & 0.0039 & 0.00038 & 0.00055 & 0.0044 & 0.0012 \\
\hline Batuku fountain & N.D. & N.D. & 0.00013 & 0.0008 & 0.0004 & 0.000137 & 0.00061 & 0.0054 & 0.0014 \\
\hline Kavignonge spring & N.D. & 0.00004 & 0.00021 & 0.0029 & 0.0039 & 0 & 0.00055 & 0.0085 & 0.0013 \\
\hline Kinawa spring & N.D. & 0.00012 & 0.00081 & 0.0007 & N.D. & 0.00011 & 0.00045 & 0.0074 & 0.0014 \\
\hline Kavasembe River & 0.00045 & 0.00004 & 0.00038 & 0.0022 & N.D. & 0.00038 & 0.00042 & 0.0014 & 0.0012 \\
\hline Apres Muko River & N.D. & 0.0002 & 0.00047 & 0.0004 & 0.0074 & 0.00043 & 0.00039 & 0.0055 & 0.0012 \\
\hline Kalimbuta River & 0.00045 & N.D. & 0.00064 & 0.0005 & N.D. & 0.00038 & 0.00039 & 0.0063 & 0.0013 \\
\hline Kasondo River & N.D. & N.D. & 0.00064 & 0.0005 & N.D. & 0.00025 & 0.00039 & 0.007 & N.D. \\
\hline Kasondo Spring & 0.00045 & 0 & 0.00047 & 0 & 0.0039 & 0.00092 & 0.00055 & 0.0064 & 0.0012 \\
\hline Kavutika River & N.D. & N.D. & N.D. & 0.0014 & 0.0004 & 0.00029 & 0.00058 & 0.0058 & 0.0009 \\
\hline Kisaka River & 0.0003 & 0.00012 & 0.00047 & 0.0007 & 0.0039 & 0.00025 & 0.00058 & 0.0093 & 0.0014 \\
\hline Kyalimbwa River & N.D. & 0.00004 & N.D. & 0.0006 & 0.0039 & 0.00029 & 0.00055 & 0.0093 & 0.0016 \\
\hline Kyavinyonge River & N.D. & 0.00012 & 0.00047 & 0.0028 & 0.0004 & 0.00002 & 0.00058 & 0.0073 & N.D. \\
\hline Kyavinyonge Spring & 0.00045 & N.D. & N.D. & 0.0003 & 0.0004 & 0.00011 & 0.00045 & N.D. & 0.0013 \\
\hline $\mathrm{Lac} 10 \mathrm{~m}$ & 0.0012 & 0.00004 & 0.00047 & 0.0006 & 0.0039 & 0.00011 & 0.0005 & 0.0063 & 0.0045 \\
\hline Lac $200 \mathrm{~m}$ & 0.0003 & 0.00012 & 0.00064 & 0.0005 & 0.0039 & 0.00002 & 0.00039 & 0.0057 & 0.0028 \\
\hline $\mathrm{Lac} 500 \mathrm{~m}$ & N.D. & 0.00012 & N.D. & 0.0004 & 0.0004 & N.D. & 0.00053 & 0.0068 & 0.0017 \\
\hline Biodi ground water & 0.00045 & N.D. & 0.00047 & 0.0005 & 0.0004 & 0.0043 & 0.00053 & 0.0053 & 0.0013 \\
\hline Lunyasenge River & 0.00105 & 0.00012 & 0.00064 & 0.0007 & 0.0004 & 0.00025 & 0.00053 & 0.008 & 0.002 \\
\hline Murhamba River & N.D. & N.D. & 0.00038 & 0.0005 & 0.0039 & 0.00029 & 0.00039 & 0.007 & 0.0012 \\
\hline Musenda River & 0.0003 & N.D. & N.D. & 0.0029 & 0.0074 & 0.00011 & 0.00039 & 0.012 & 0.0014 \\
\hline Mutikili River & 0.00045 & N.D. & 0.00064 & 0.0002 & 0.0039 & N.D. & 0.00055 & 0.0064 & 0.0012 \\
\hline Muwe River & 0.0012 & 0.00004 & 0.00021 & 0.0025 & 0.0074 & 0.00047 & 0.00042 & 0.0098 & 0.0012 \\
\hline Kinawa River & 0.00045 & 0.00012 & 0.00047 & 0.0005 & 0.0031 & 0.0002 & 0.0005 & 0.0064 & 0.0015 \\
\hline Rutshuru Lb River & 0.0012 & N.D. & 0.00047 & 0.0007 & 0.0004 & 0.00025 & 0.00053 & 0.0068 & 0.0015 \\
\hline Rwindi River & N.D. & 0.00012 & 0.00081 & 0.0007 & 0.0039 & N.D. & 0.00058 & 0.0054 & 0.0015 \\
\hline Semliki River & 0.00195 & 0.00004 & 0.00047 & 0.0005 & 0.0039 & 0.00016 & 0.0005 & 0.0061 & 0.0015 \\
\hline Singamwambe River & 0.0012 & 0 & 0.00064 & 0.0013 & 0.0004 & 0.00029 & 0.00053 & 0.0054 & 0.0014 \\
\hline Tsere River & 0.00045 & N.D. & 0.00047 & N.D. & 0.0004 & 0.00038 & 0.00061 & 0.0054 & 0.0012 \\
\hline Vitshumbi River & 0.00045 & 0.00004 & 0.00081 & 0.0016 & 0.0039 & 0.00029 & 0.00042 & N.D. & 0.0012 \\
\hline
\end{tabular}

${ }^{*}$ in brackets is the maximum value required by standards for natural potable water, in mg/l; N.D.: Not Detected. 
Table 4. Bacteriological analyze of water in Lake Eduard and around the watershed $(\mathrm{col} / \mathrm{mL})$.

\begin{tabular}{|c|c|c|c|c|c|c|c|}
\hline Sites & $\begin{array}{l}\text { Citrobacter } \\
(\mathrm{col} / \mathrm{mL})\end{array}$ & $\begin{array}{c}\text { Enterobacter } \\
(\mathrm{col} / \mathrm{mL})\end{array}$ & $\begin{array}{l}\text { Klebsiella } \\
(\mathrm{col} / \mathrm{mL})\end{array}$ & $\begin{array}{l}\text { Hafnia } \\
(\mathrm{col} / \mathrm{mL})\end{array}$ & $\begin{array}{c}\text { E. coli } \\
(\mathrm{col} / \mathrm{mL})\end{array}$ & $\begin{array}{l}\text { Cholerae } \\
(\mathrm{col} / \mathrm{mL})\end{array}$ & $\begin{array}{c}\text { Salmonella } \\
\text { \& Shigella } \\
(\mathrm{col} / \mathrm{mL})\end{array}$ \\
\hline Semiliki River & 0 & 0 & 0 & 0 & 0 & 0 & 0 \\
\hline Kagezi River & 0 & 0 & 3200 & 0 & 0 & 0 & 0 \\
\hline Ikanga 1 River & 2000 & 0 & 0 & 0 & 0 & 0 & 0 \\
\hline Ikanga Torrent River & 0 & 0 & 0 & 0 & 1400 & 0 & 0 \\
\hline Sans nom River & 0 & 2200 & 0 & 0 & 0 & 0 & 0 \\
\hline Ntungwe River & 0 & 0 & 0 & 0 & 0 & 0 & 0 \\
\hline Kisaka River & 0 & 3300 & 0 & 0 & 10,000 & 0 & 0 \\
\hline Rutshuru River & 0 & 4800 & 0 & 0 & 0 & 0 & 0 \\
\hline Katundu River & 0 & 0 & 0 & 0 & 0 & 0 & 0 \\
\hline Murhamba 2 River & 0 & 0 & 3000 & 0 & 0 & 0 & 0 \\
\hline Rwindi River & 0 & 5000 & 0 & 0 & 0 & 0 & 0 \\
\hline Butuku fountain & 0 & 0 & 5800 & 0 & 0 & 0 & 0 \\
\hline Muwe River & 0 & 3500 & 0 & 0 & 0 & 0 & 0 \\
\hline Kyavinyonge Spring & 0 & 800 & 0 & 0 & 0 & 0 & 0 \\
\hline CEBK fountain & 0 & 0 & 0 & 0 & 5500 & 0 & 0 \\
\hline Kinawa River & 3300 & 0 & 0 & 0 & 0 & 0 & 0 \\
\hline Katiri fountain & 0 & 0 & 0 & 0 & 5500 & 0 & 0 \\
\hline Biondi ground water & 0 & 0 & 2000 & 0 & 5000 & 0 & 0 \\
\hline Gite 1 fountain & 0 & 0 & 0 & 0 & 0 & 0 & 0 \\
\hline Kavasembe fountain & 0 & 6000 & 0 & 0 & 0 & 0 & 0 \\
\hline Ikanga 2 River & 0 & 0 & 3000 & 0 & 0 & 0 & 0 \\
\hline Karukumbwa River & 0 & 0 & 0 & 0 & 5000 & 0 & 0 \\
\hline Kyalibwa River & 0 & 0 & 0 & 0 & 4400 & 0 & 0 \\
\hline Gite fountain & 0 & 0 & 0 & 0 & 0 & 0 & 0 \\
\hline Katana fountain & 0 & 0 & 0 & 0 & 0 & 0 & 0 \\
\hline Apres Muko & 0 & 0 & 0 & 0 & 0 & 0 & 0 \\
\hline Mulera spring & 0 & 0 & 0 & 1050 & 0 & 0 & 0 \\
\hline Kavutika fountain & 0 & 0 & 0 & 0 & 0 & 0 & 0 \\
\hline Lunyasenge River & 0 & 4500 & 0 & 0 & 0 & 0 & 0 \\
\hline Musenda River & 0 & 0 & 0 & 0 & 1700 & 0 & 0 \\
\hline Kisaka Spring & 6500 & 0 & 0 & 0 & 0 & 0 & 0 \\
\hline Kisaka 1 River & 0 & 6000 & 0 & 0 & 5000 & 0 & 0 \\
\hline Muko River & 0 & 0 & 0 & 0 & 0 & 0 & 0 \\
\hline Lubiriya River & 2000 & 0 & 0 & 0 & 0 & 0 & 0 \\
\hline Kyavinyonge $0 \mathrm{~m}$ large & 0 & 2800 & 0 & 0 & 3000 & 0 & 0 \\
\hline Kyavinyonge $200 \mathrm{~m}$ large & 0 & 0 & 0 & 0 & 0 & 0 & 0 \\
\hline Kyavinyonge $800 \mathrm{~m}$ large & 0 & 0 & 0 & 0 & 0 & 0 & 0 \\
\hline Murhamba River & 0 & 0 & 0 & 0 & 0 & 0 & 0 \\
\hline Muko Chute 2 & 4800 & 0 & 0 & 0 & 0 & 0 & 0 \\
\hline Ancien Murhamba River & 0 & 0 & 0 & 0 & 0 & 0 & 0 \\
\hline Kalibuta river & 0 & 2200 & 0 & 0 & 0 & 0 & 0 \\
\hline Rwessa River & 0 & 0 & 0 & 0 & 2500 & 0 & 0 \\
\hline Muharabu spring & 0 & 0 & 6500 & 0 & 0 & 0 & 0 \\
\hline
\end{tabular}


poor hygiene practices. This is also observed in sites where water was contaminated with Enterobacteria. This contamination of water with pathogens is reported at the source but may also occur during handling in households or other working places as reported in other studies [47]. Inadequate protection of water collection and storage containers and unhygienic conditions contribute to contamination at home.

The results also revealed that population living in Lake Eduard watershed who consumes water from shallow wells, Lake, rivers and some fountains without treatment stands the risk of bacteria diseases as the concentration of bacteria exceeds the WHO recommended limit. However, education and awareness on health risk associated with the consumption of untreated water is necessary.

Macroinvertebrate fauna different rivers in the watershed are presented in $\mathrm{Ta}$ ble 5 below during the sampling period.

Macroinvertebrate varied from river to river in Lake Eduard watershed. The highest specific richness was found in Semuliki, Musenda and Lubiriyarivers. The orders of Ephemeroptera and Diptera are largely represented in the collection. Some species are rarely found in the rivers. The Order of Tricoptera is represented with only 2 families. The presence of Bellamya contracta was reported in astudy by Brown [48]. Snails, the intermediate host of schistosomiasis, were also found in the rivers and can contribute to the expansion of schistosomiasis in the watershed. These snails are Biomphalaria pfeifferi, Biomphalaria sudanica, Bulinus truncatus and Ferrissia burnipi [49].

The comparison of specific richness for dry and wet season in the Lake Eduard watershed is presented in Figure 2.

Figure 2 shows that specific richness varied in rivers from 0 to 7 . The high value was recorded in the river Lubiriya in dry season while the lowest ( 0 taxa) was found in wet season in Karukumba and Kisaka after rivers and also in dry season in Kalibuta River. In wet season the high runoff in rivers are pointed as the source of disappearance of many taxa while in dry season Kalibuta river forms a delta distroying the habitat of macroinvertebrate. The number of individual taxa varied also from river to river during the two sampling seasons (Figure 3).

The highest number of taxa was recorded in Karukumba River with 44 individuals in wet season. In general in wet season the number of indivudual taxa was high than in dry season. But comparatively to other tropical region, this number is low [17].

\section{Conclusion}

Variation in all the physicochemical parameters, bacteriological parasites and the macroinvertebrate assemblage were recorded around Lake Eduard watershed. Although some of the parameters of rivers conform to the WHO standard for drinking water, it still needs to be treated since parameters have values that are above the WHO standard for drinking water. Some species of macroinvertebrates 


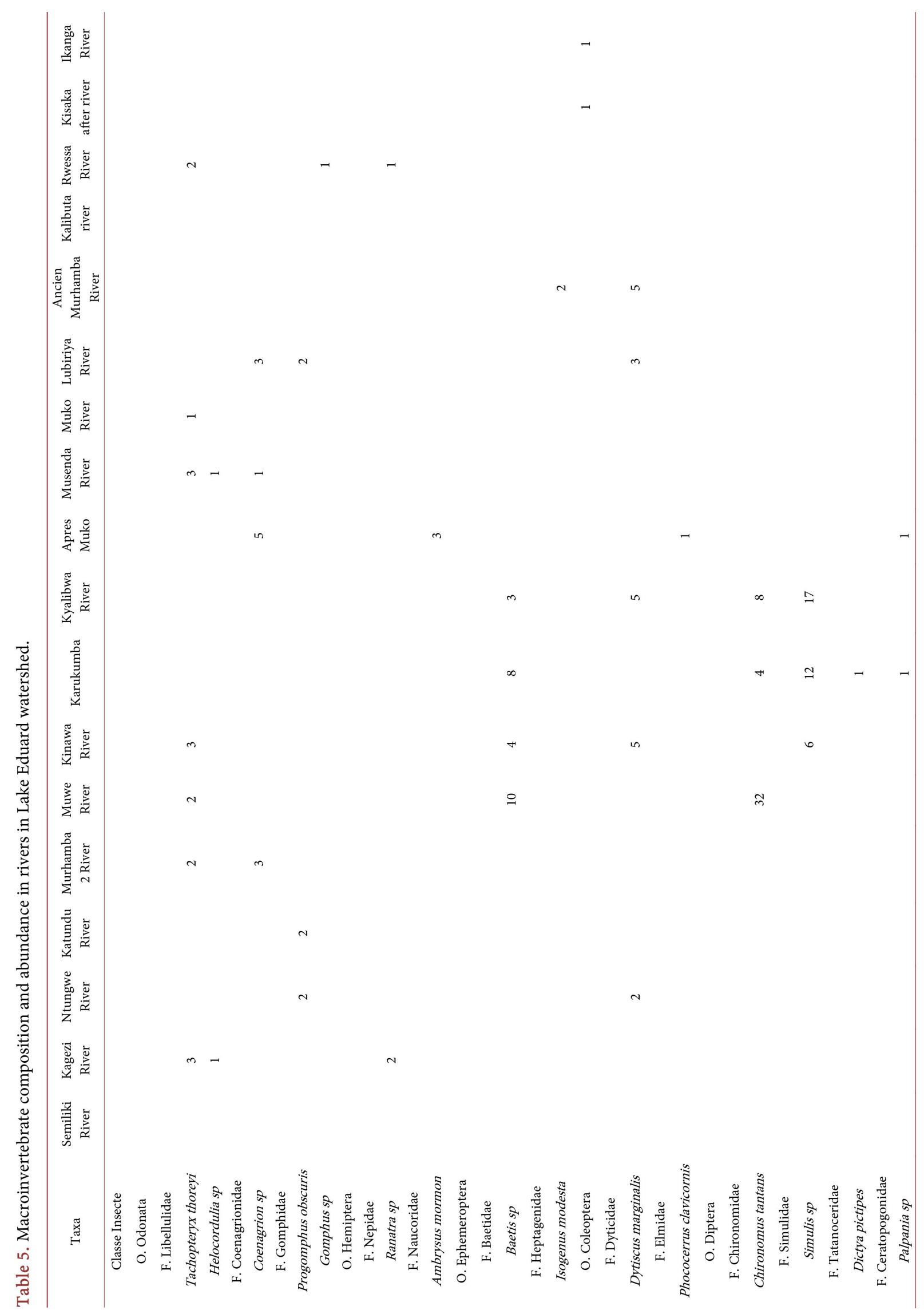




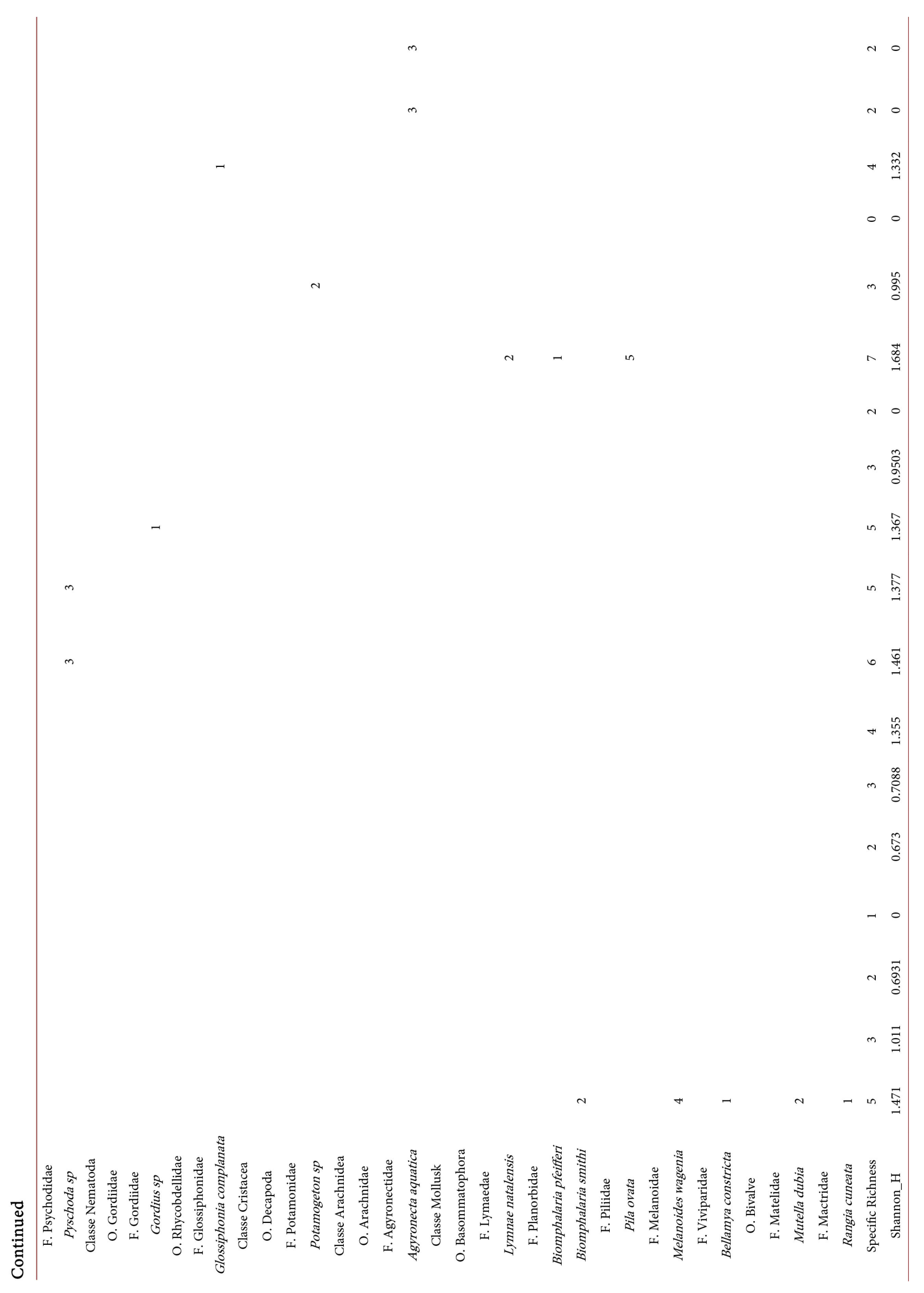




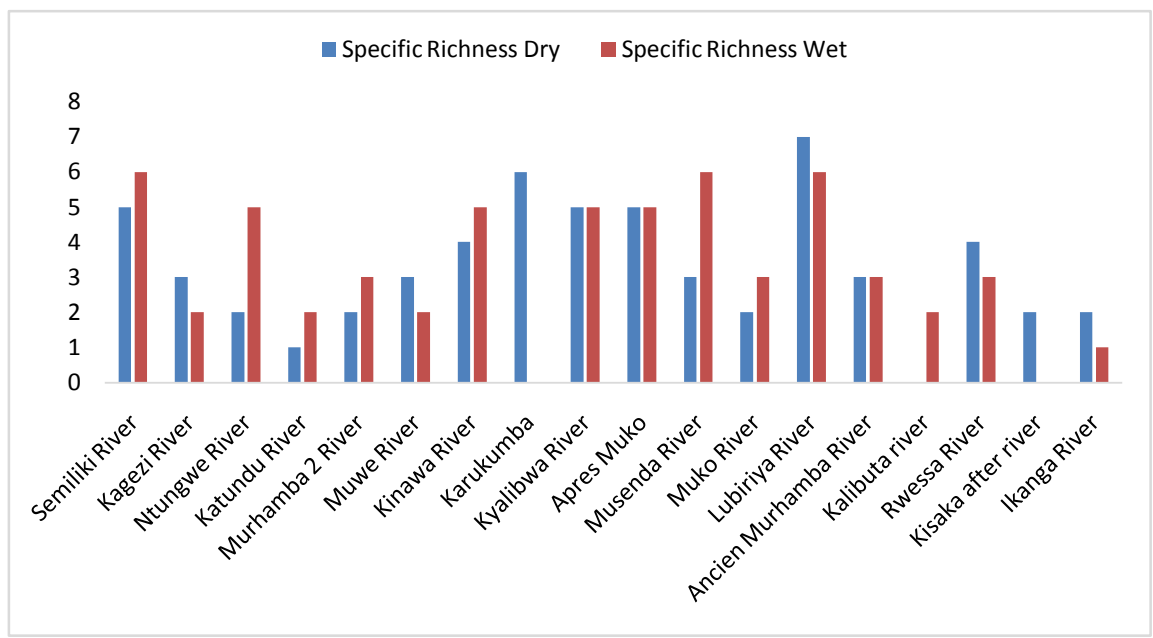

Figure 2. Seasonal variation of specific richness in Lake Eduard watershed.

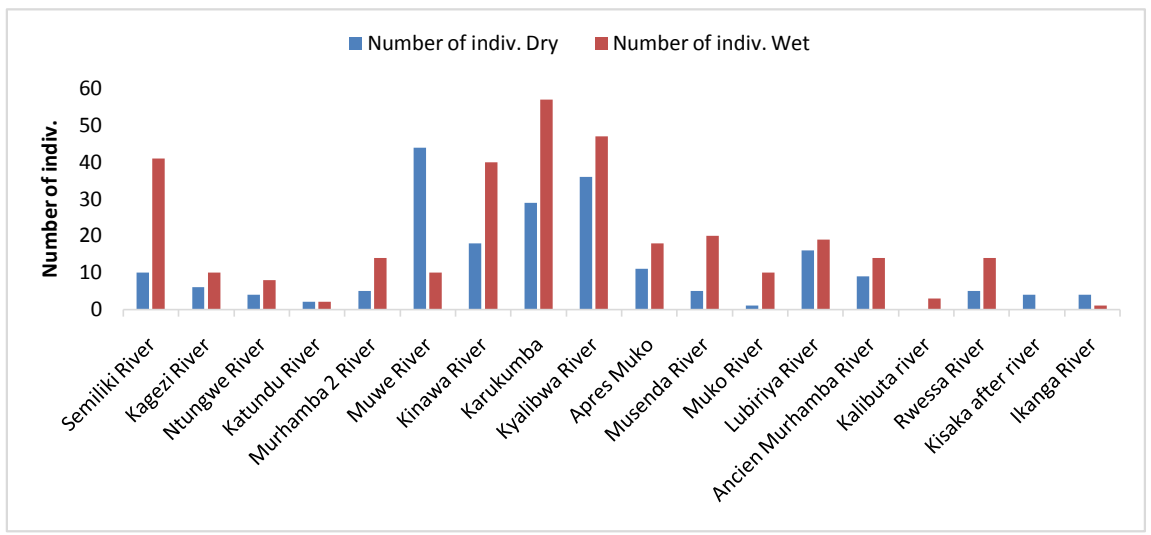

Figure 3. Seasonal variation of number of indivual taxa in Lake Eduard watershed.

are the intermediate host of many diseases including schistosomiasis and fasciolosis. Regular monitoring of water bodies with required number of parameters in relation to water quality to prevent the outbreak of diseases and occurrence of hazards should be considered. Bacteriological water quality should be carried out for a longer period of time to get a more clear idea about the water quality in the watershed. To understand variations of water quality in the Lake Eduard watershed, more sampling time in the watershed is needed.

\section{Conflicts of Interest}

The authors declare no conflicts of interest regarding the publication of this paper.

\section{References}

[1] Dodson, S.I. (2005) Introduction to Limnology. McGraw-Hill, Inc., New York, 400 p.

[2] Patil, P.N., Sawant, D.V. and Deshmukh, R.N. (2012) Physico-Chemical Parameters for Testing of Water-A Review. International Journal of Environmental Sciences, 3, 1194-1207. 
[3] Parikh, P. (2015) Status of Fluoride Contamination in Soil, Water and Vegetation at Kadipani Fluorspar Mine. International Journal of Allied Practice, Research and Review, 2, 100-105.

[4] Shrivastava, A., Tandon, S.A. and Kumar, R. (2015) Water Quality Management Plan for Patalganga River for Drinking Purpose and Human Health Safety. International Journal of Scientific Research in Environmental Sciences, 3, 71-87. https://doi.org/10.12983/ijsres-2015-p0071-0087

[5] Gorde, S.P. and Jadhav, M.V. (2013) Assessment of Water Quality Parameters: A Review. Journal of Engineering Research and Applications, 3, 2029-2035.

[6] Adeyeye, E.I. (1994) Determination of Heavy Metals in Illisha africana, Associated Water, Soil Sediments from Some Fish Ponds. International Journal of Environmental Study, 45, 231-240. https://doi.org/10.1080/00207239408710898

[7] Reda, A.H. (2016) Physico-Chemical Analysis of Drinking Water Quality of Arbaminch Town. Journal of Environmental and Analytical Toxicology, 6, 356.

[8] Kulkarni, G.J. (1997) Water Supply and Sanitary Engineering. 10th Edition, Farooq Kitabs Ghar, Karachi, 497.

[9] Milkiyas, T., Mulugeta, K. and Bayeh, A. (2011) Bacteriological and Physicochemical Quality of Drinking Water and Hygiene-Sanitation Practices of the Consumers in Bahir Dar City, Ethiopia. Ethiopian Journal of Health Sciences, 21, 19-26. https://doi.org/10.4314/ejhs.v21i1.69040

[10] Ellis, K.V. (1989) Surface Water Pollution and Its Control. Macmillan Press Ltd., Basingstoke and London.

[11] Adefemi, S.O. and Awokunmi, E.E. (2010) Determination of Physico-Chemical Parameters and Heavy Metals in Water Samples from Itaogbolu Area of Ondo-State, Nigeria. African Journal of Environmental Science and Technology, 4, 145-148. https://doi.org/10.5897/AJEST09.133

[12] WHO (2004) Guidelines for Drinking-Water Quality. World Health Organization, Geneva.

[13] Mbalassa, M., Bagalwa, M., Nshombo, M. and Kateyo, M. (2014) Assessment of Physicochemical Parameters in Relation with Fish Ecology in Ishasha River and Lake Edward, Albertine Rift Valley, East Africa. International Journal of Current Microbiology and Applied Sciences, 3, 230-244.

[14] Kilham, P. (1984) Sulfate in African Inland Waters: Sulfate to Chloride Ratios. Verhandlungen der international Vereinigung fur Limnology, 22, 296-302. https://doi.org/10.1080/03680770.1983.11897306

[15] Lehman, J.T. (2002) Application of Satellite AVHRR to Water Balance, Mixing Dynamics, and the Chemistry of Lake Edward, East Africa. In: The East African Great Lakes. Limnology, Palaeolimnology and Biodiversity, Kluwer Academic Publishers, Dordrecht, 235-260. https://doi.org/10.1007/0-306-48201-0_8

[16] Talling, J.F. and Talling, I.B. (1965) The Chemical Composition of African Lake Waters. Hydrobiologia, 50, 421-463. https://doi.org/10.1002/iroh.19650500307

[17] Bagalwa, M., Majaliwa, J.G.M., Mushagalusa, N. and Karume, K. (2013) Estimation of Transported Pollutant Load from Small Urban Kahuwa River Micro-Catchment in Lake Kivu, Democratic Republic of Congo. Journal of Environment Science and Engineering B, 2, 460-472.

[18] Russell, J.M. and Johnson, T.C. (2006) The Water Balance and Stable Isotope Hydrology of Lake Edward, Uganda-Congo. Journal of Great Lakes Research, 32, 77-90. https://doi.org/10.3394/0380-1330(2006)32[77:TWBASI]2.0.CO;2 
[19] Beadle, L.C. (1981) The Inland Waters of Tropical Africa: An Introduction to Tropical Limnology. Second Edition, Longman Inc., New York.

[20] Damas, H. (1937) Exploration du Parc National Albert. Mission H. Damas (1935-1936) Fascicule 1. Recherches Hydrobiologiques dans les Lacs Kivu, Edward et Ndalaga.

[21] Harrelson, C.C., Rawlins, C.L. and Potyondy, J.P. (1994) Stream Channel Reference Sites: An Illustrated Guide to Field Technique. Gen. Tech. Rep. RM-245. US Department of Agriculture, Forest Service, Rocky Mountain Forest and Range Experiment Station, Fort Collins, 61 p. https://doi.org/10.2737/RM-GTR-245

[22] Bartram, J. and Balance, R. (1996) Water Quality Monitoring: A Practical Guide to the Design of Freshwater Quality Studies and Monitoring Programmes. Chapman \& Hall, London.

[23] Michaud, J.P. and Wierenga, M. (2005) Estimating Discharge and Stream Flows. A Guide for Sand and Gravel Operators. Ecology Publication Number 05-10-070, 37 p.

[24] Golterman, H.L., Clymo, R.S. and Ohnstad, M.A.M. (1978) Methods for Physical and Chemical Analysis of Fresh Waters. Blackel Scientific Publication, London, 213 p.

[25] APHA (American Public Health Association) (1989) Standard Methods for the Examination of Water and Wastewater. American Water Works Association, Water Environment Federation, USA, 18nd Edition, American Public Health Association, Washington DC.

[26] Wetzel, R.G. and Likens, G.E. (2000) Limnological Analysis. Springer, Berlin, 429 p. https://doi.org/10.1007/978-1-4757-3250-4

[27] Olapande, O.J. and Omitoyin, B.O. (2012) Anthropogenic Pollution Impact on Physico-Chemical Characteristics of Lake Kivu, Rwanda. Scholarly Peer Reviewed, 12, 6517-6536.

[28] Olapande, O.J. (2011) Trace Metal Pollution and Physicochemical Characteristics of Lake Kivu, Rwanda. Global Journal of Environmental Research, 5, 56-64.

[29] UNECE (1994) Standard Statistical Classification of Surface Freshwater Quality for the Maintenance of Aquatic Life. In: Readings in International Environment Statistics, United Nations Economic Commission for Europe, United Nations, New York and Geneva, 53-64.

[30] FEPA (1991) Guidelines and Standards for Environmental Pollution Control in Nigeria, Federal Environmental Protection Agency Regulation 1991 on Pollution Abatement in Industries and Facilities Generated Wastes. 78, 42, 38 p.

[31] WHO (1993) Guidelines for Drinking-Water Quality. Second Edition, Volume 1 Recommendations. World Health Organization, Geneva, 11 p.

[32] ISO (1986) Water Quality-Determination of Cobalt, Nickel, Copper, Zinc, Cadmium and Lead-Flame Atomic Absorption Spectrometric Methods. In: International Standard, Vol. 1986, International Organisation of Standardisation, Geneva, 11.

[33] ISO (2012) Water Quality-Determination of Mercury-Method Using Atomic Absorption Spectrometry (AAS) with and without Enrichment. In: International Standard, Vol. 2012, International Organisation of Standardisation, Geneva, 15.

[34] ISO (2012) Water Quality-Determination of Iron-Spectrometric Method Using 1,10-Phenanthroline. In: International Standard, International Organisation of Standardisation, Geneva, 4.

[35] SCA (Standing Committee of Analysts) (2002) The Microbiology of Drinking Water. Part 1-Water Quality and Public Health. Methods for the Examination of Waters and Associated Materials. Environment Agency, Bristol. 
[36] Olivier, L. and Scheiderman, M. (1956) Method for Estimation of the Density of Aquatic Snail Population. Experimental Parasitology, 5, 109-117. https://doi.org/10.1016/0014-4894(56)90008-X

[37] Needham, J.G. and Needham, P.R. (1962) A Guide to the Study of Freshwater Biology. Holden Day, Inc., San Francisco.

[38] Micha, J.C. and Moiset, J.L. (1982) Evaluation biologique de la pollution de ruisseaux et rivières par les macroinvertébrés aquatiques. Probio Revue, 5, 142 p.

[39] Karume, K., Bagalwa, M., Yalire, M., Kazi, K., Bagula, E.M., Bitariho, R., Nahayo, D., Kasangaki, A. and Byamukama, J. (2016) Hydrological Systems in the Greater Virunga Landscape: Water Quality around Mikeno Sector. Journal of Water Resource and Protection, 8, 382-396. https://doi.org/10.4236/jwarp.2016.83032

[40] Waziri, M. and Ogugbuaja, V.O. (2010) Interrelationships between Physicochemical Water Pollution Indicators: A Case Study of River Yobe-Nigeria. American Journal of Scientific and Industrial Research, 1, 76-80.

[41] Brekke, L.D., Kiang, J.E., Olsen, J.R., Pulwarty, R.S., Raff, D.A., Turnipseed, D.P., Webb, R.S. and White, K.D. (2009) Climate Change and Water Resources Management-A Federal Perspective. USA Geological Survey Circular 1331, 65 p. http://pubs.usgs.gov/circ/1331 https://doi.org/10.3133/cir1331

[42] Bagalwa, M., Yalire, M., Balole, E. and Karume, K. (2014) A Preliminary Assessment of Physico Chemical and Bacteriological Characteristics of Lake Edward and Majors Tributaries Rivers, Democratic Republic of Congo. Scholars Academic Journal of Biosciences, 2, 236-245.

[43] Aghui, N. and Biémi, J. (1984) Geology and Hydrogeology of Groundwater in the Region of Abidjan and Contamination Risks. Annals of the National University of Côte d' Ivoire Series C, 20, 331-347.

[44] Loko, S., Ahoussi, K.E., Koffi, Y.B., Kouassi, A.M. and Biémi, J. (2013) Anthropogenic Activities and the Degradation of the Environmental Quality in Poor Neighborhoods of Abidjan, Côte d'Ivoire: Abia Koumassi Village. Journal of Environmental Protection, 4, 1099-1107. https://doi.org/10.4236/jep.2013.410126

[45] Best, G.A., Bogacka, T. and Niemirycz, E. (1998) International River Water Quality: Pollution and Restoration. Taylor and Francis, London, 310.

[46] Jain, A.K. (2009) River Pollution. APH Publishing, New Delhi, 330.

[47] WHO (2004) Guidelines for Drinking Water Quality: Supporting Documentation to Guidelines. 3rd Edition, 2552 p.

[48] Brown, S.D. (1994) Freshwater Snails of Africa and Their Medical Importance. Taylor and Francis, London, 487 p.

[49] Bagalwa, M. and Baluku, B. (1997) Distribution des mollusques hôtes intermédiaires des schistosomoses humains à Katana, Sud-Kivu, Est du Zaïre. Médecine Tropicale, 57, 369-372. 